Comparative Philosophy Volume 13, No. 1 (2022): 119-138

Open Access / ISSN 2151-6014 / www.comparativephilosophy.org

https://doi.org/10.31979/2151-6014(2022).130109

\title{
A SONOGRAM OF THE DARK SIDE OF THE DAO: THE POSSIBILITY OF ANTINATALISM IN DAOISM
}

\author{
ROBBERT ZANDBERGEN
}

\begin{abstract}
In the present work I study Daoist philosophy in conjunction with the radical new philosophy of antinatalism, spearheaded by South African philosopher David Benatar. Although I am not claiming equivalence between the two, a meaningful communication emerges between the classical Chinese sources used here and the modern doctrine of antinatalism. I argue that both visions partake in a radical critique of consciousness according to which this faculty of the human mind is far from what it is often held to be. In fact, it is perceived as a destructive and disruptive element of, and in, existence. Moreover, both offer a praxis of return that seeks to undo this disruption. In the case of Daoism, consciousness pushes humans ever farther away from the Dao. It is imperative to return from this exile, and to return to the Dao. This can, radically, only be achieved by the return from 'ordinary' conscious existence. This is the prerogative of sagehood. It will be shown that the trajectory of sagehood shares important parameters with the antinatalist quest to significantly (and perhaps conclusively) challenge human hubris in the cosmos at large, and to reinstate cosmic humility.
\end{abstract}

Keywords: antinatalism, consciousness, Daoism, reproduction, sagehood, suffering

\section{INTRODUCTION}

In the present work I capture an image of the dark side of the Dao that testifies to a grim metaphysical system that I will analyze using the concepts of the modern philosophy of antinatalism, which refers to the philosophical position that humankind should cease reproduction in order to contribute to the phased extinction of conscious, human existence. Because this view is new and radical, I will first set out to define it. I will emphasize that the radical conclusions drawn by antinatalism flow from a delicate process of philosophizing that pivots on the emergence and continued operation of human consciousness. It is held that consciousness inevitably brings about vast problems for humankind on Earth. These problems are so vast that humans cannot solve them by any other means than the radical last resort of the eradication of consciousness by the voluntary (and non-violent) abstention from procreation. Thus it is only at the

ZANDBERGEN, ROBBERT: Department of Philosophy, University of Macau. Email: robbertzandbergen@gmail.com 
endpoint of the philosophical project of antinatalism that the topic of reproduction comes into play.

Consciousness is an excellent starting point for any inquiry into Daoist philosophy. I will argue here that antinatalism and Daoism partake in a radical critique of consciousness according to which this faculty of the human mind is far from what it is often held to be. At the height of conscious hubris, studying this critique will be of the utmost importance in the twenty-first century. However, it must be stressed from the start that this is not at all to say that there is any sort of equivalence between Daoism and antinatalism or, more absurdly, that Daoism is somehow proto-antinatalism, or antinatalism somehow post-Daoism. Rather, there is an important coincidence of ideas about the increasingly disruptive pressures of human consciousness, as well as a shared emphasis on instituting a radical praxis of return that aims to restitute this.

This is not a simple 'return' to more primitive forms of living marked by less conscious interaction with the world around us. What is called for, rather, is more than the mere treatment of symptoms: the very existence of consciousness (and our unremitting reliance on it) must be reversed. Importantly, this cannot be achieved violently or abruptly for reasons that will be made clear below. According to the Daoist texts, this praxis of return should not be forced, and must be assumed spontaneously. Ultimately the Daoist posture heeds the naturalness of all things that are, by showing humility towards the Dao "itself". The trajectory of (re)discovering this corresponds to the all-important concept of return found throughout texts from the constellation of Daoist philosophical writings and which is summed up in the short, fortieth chapter in the $\mathrm{Lao}-\mathrm{Zi}$ 老子 discussed below.

While these might be radical claims, I will argue that this interpretation emerges quite naturally when we consider some of the key passages from the texts studied here. The overall anti-humanist or non-humanist credentials of Daoism are well-known. The universe is not humanity's playground. Its matters, conversely, are mere playthings. Humans are not beckoned to seek absolution for the error of the species but, rather, are tasked with rectifying the very coming-into-existence of it, rooted as it is in the continued operation of consciousness. This is not to say that humans must all die off as soon as possible. But, humans are enjoined to contribute to a careful project of the dismantling of the human project built around the institution of consciousness over the ages. The texts under discussion are, unfortunately, quiet on the matter as to why humankind then came into existence in the first place. In the face of this uncertainty, we do get the impression that humankind itself is tasked with undoing the unnecessary pressures exerted by the continued operation of its consciousness. This brings to the fore the same possibility of a cosmos emptied of human consciousness that contemporary antinatalism points towards to as well. This exposes a coincidence of concerns that invites us to look at antinatalism and Daoism in unison.

\section{WHICH CONSCIOUSNESS, WHOSE CONSCIOUSNESS?}

Although Daoist texts certainly discuss the intricacies of the human mind, there is no focused discussion on what we presently refer to as consciousness. As Ru Xin writes, 
an easy reason for this is that there is "...no concept or special term in ancient Chinese philosophy which could now be translated as "consciousness'." (Ru 1984, 78) Of course this lack of terminology does not reveal a lack of interest in matters to which we now attach definite names. The ancient Chinese had their own observations about the faculty we now comfortably refer to as "consciousness". It makes sense, therefore, to excavate these observations from the texts at our disposal, and to compare these with more familiar (psychological) ideas regarding human consciousness.

In the early 1990s, Harold D. Roth argued that "[o]ne genuinely unexplored area of early Chinese thought is that of psychology." (Roth 2021, 21) ${ }^{1}$ Like Ru, Roth argues that this is no evidence of an overall lack of interest in this all-important topic. When we investigate ancient Chinese understandings of the human mind, a picture of consciousness emerges that opens an important window on the Chinese worldview as such. We can string together pieces of evidence from the texts and construct a working definition of consciousness as the consolidation of entrenched awareness that follows from the increased interaction between humans, as well as between human and nonhuman, and that goes beyond the 'naturally' necessary. Although animals may certainly be conscious of predators, for instance, and consequently can choose to run away, this is not the sense of consciousness alluded to here. Specifically human consciousness denotes a more disruptive, or even exaggerated, awareness of the world at large, and one that especially inflates the position of the conscious human itself in this scheme. Both contemporary antinatalism and classical Daoism view the development of consciousness as an aberration in an otherwise fluid and fluent universe marked by some sense of non-human harmony, stability and tranquility. While Daoist texts and thinkers seem more interested in the 'state' of this non-human harmony, modern-day antinatalists more often focus on the nature of the aberration presented by human consciousness.

It is important to note that the development of consciousness may be perfectly "natural" from the perspective of the human, but not so from the non-perspective of the non-human, or the Dao. Thus, concomitant with the very ageing process is the deepening and sharpening of consciousness as a repository of more information and a tool better equipped to process any information that emerges from the interaction with the world around. Daoist texts and authors, however, view this 'natural' process a disruptive, and as a deviation from the ordinary ways of the Dao. This ultimately leads to a strange schism between human and non-human that can be overcome by following the trajectory of sagehood as it is laid out in various texts at our disposal. The institutionalization of consciousness that marks modernity is thereby regarded as highly "unnatural", as counter-intuitive as this sounds. Although there is no notion of an antinatalist sage, the sagely antinatalist would undoubtedly, and on their own accord, stop the wheel of reproduction (for any of a variety of reasons).

\footnotetext{
${ }^{1}$ This originally appeared in a 1991 article, "Psychology and Self-Cultivation in Early Taoistic Thought," that was recently added to a compilation of some of Roth's more memorable contributions to the study of Chinese philosophy.
} 


\section{ANTINATALISM DEFINED}

The word 'antinatalism' consists of 'anti-' and 'natalis' and simply means "against birth". In spite of this linguistic hint, antinatalism also refers to a specifically modern view that emphasizes the negative aspect(s) of conscious existence. From this flows a sort of policy recommendation concerning reproduction. More specifically, it might inspire the view that reproduction should be stopped altogether. As mentioned before, this extreme measure only emerges from a delicate process of philosophizing. In fact, it is not difficult to think of reasons not to have children, and birth-rates are consistently going down in virtually all of the developed world. We can choose to focus on our careers rather than on building a family. We can also think of the looming effects of climate change or societal injustice as negatively impacting our choice to reproduce. It is also not too difficult to think of unfortunate accidents that literally make it impossible to have children. A terrible accident may take away one's reproductive capabilities if the damage sustained to the reproductive organs is sufficiently grave. Moreover, some people are simply born biologically unable to reproduce. While these reasons might all lead one towards (temporary) childlessness, in themselves they are insufficient to warrant the radical conclusions drawn by antinatalism as a more thorough, philosophical position. ${ }^{2}$

For this we need something more profound than practical considerations alone. We need the conviction that there is something inherently wrong with human beings that necessitates the conclusion that we should cease giving birth to them, otherwise we could choose significantly less decisive measures to solve our problems. ${ }^{3}$ Therefore, only when there is something fundamentally wrong with humans can we warrant the conclusion that we should not 'create' any more of them. In philosophical antinatalism, the underlying thought is that consciousness brings about so much suffering that it would have been better if we had never come into existence (Benatar 2006, 2, 83, 136n, 164). Because we already are in existence, second best for us is to retroactively dismantle the artifice of human consciousness, by the cessation of human reproduction. This radical view is spearheaded by South African analytical philosopher David Benatar. ${ }^{4}$ His starting point is the observation that reproduction presents grave (but often ignored) moral dilemmas, and he laments the fact that people do not give this any consideration as a serious moral and philosophical topic (Benatar 2010, 9). Ultimately this is their loss.

For Benatar argues that birth always constitutes a net harm, and not just in the more destitute parts of the world. ${ }^{5}$ This is so because giving birth implies giving birth to a conscious human being (or at least to a being with the potential for conscious development), and consciousness is seen as the trigger of suffering (Benatar and

\footnotetext{
${ }^{2}$ Elsewhere I make a distinction between reactionary/activist and originary/philosophical antinatalism(s). See Zandbergen (2021a) for an account of this. See also Zandbergen (2021b) for a more detailed overview of (the contemporary rise of) antinatalism.

${ }^{3}$ In other words, we would be breaking a butterfly on the wheel, which is crude as it is excessive.

${ }^{4}$ See also Belshaw (2012) for an alternative account of antinatalism.

${ }^{5}$ See Smuts (2014) for a rejection of this.
} 
Wasserman 2015, 130). But, the realization of this is craftily kept at a distance by the vast majority of humans. Benatar argues that this is done by any of a number of psychological defense mechanisms that portray life as more pleasant than it actually is. Coincident with this is the, in his eyes, false belief that reproduction is largely in line with basic human morality. Throughout life we are inculcated with thoughts that reproduction is healthy for society and necessary for civilizational continuity. But, this sidesteps the great suffering that lies in wait for the newborn. ${ }^{6}$ This bitter truth ultimately renders our lives much worse than we are likely to admit (Benatar 2012, 151). While we could bluntly attribute this to misanthropy, the radical conclusions offered by antinatalism actually follow from great moral concern about the world.

In order to stop suffering, the wheel of human reproduction must be stopped in order to halt the perpetuation of consciousness that brings about this suffering in the first place. Ultimately, then, as paradoxical as this may sound, Benatar and his colleagues are occupied with the eradication of suffering. The fact that this necessitates the eradication of consciousness, and therefore the eradication of the human species (at least as we know it) is an unfortunate side-effect. On the face of things, the elimination of suffering takes precedence over the otherwise senseless perseverance of the human species, "condemned" as humans are to suffer by their consciousness. Ultimately, antinatalism ponders the final "return" from the tenacious state of suffering, which can only happen when we rid ourselves of consciousness. This movement of return, therefore, springs from profound moral concern. ${ }^{7}$

Described as such, antinatalism might seem like a very particular philosophical view, that emerged from a very specific social and intellectual atmosphere. The argument here is that this profound philosophical critique of consciousness (and the praxis of return that it offers) is interesting from a comparative and post-comparative philosophical perspective. I will now begin to outline a shared interest in such matters from a time and place vastly different from people like Benatar's intellectual and academic environment. When we think about antinatalism in the Asian context, Buddhism may come to mind first. Writing under the pseudonym of Ken Coates, Indian scholar Ramesh Mishra argued that the autochthonous religions of the Indian subcontinent - Buddhism and Brahmanism - contained the gist of what we now refer

\footnotetext{
${ }^{6}$ This is but one part of Benatar's argumentative strategy (which is phrased differently and expanded in later works). The other main argument in his 2006 work is the more technical 'asymmetry argument' which illustrates the relative benefit of the antinatalist point of view without the graphic depictions of violence, suffering, death, illness, etc. that adorn the more pessimistic quality-of-life argument. In union, these two arguments flesh out Benatar's antinatalist position.

${ }^{7}$ Because of the unignorable weight of the topics that procreational ethicists juggle with, Philipp Schönegger argues that not taking antinatalism into serious consideration could have a significant and extra-philosophical impact upon future generations. This is why he argues that “...it remains scientifically interesting to investigate whether the endorsement of such views stands in a relationship to particular personality traits." (Schönegger 2021, 4) Schönegger finds that there is indeed a link between two of the so-called dark triad personality traits-Machiavellianism and psychopathy-and antinatalist views (Ibid., 16), essentially countering Benatar's own assertions to be acting out of kindness. Importantly, however, Schönegger's account deals with lay people and not with professional philosophers like Benatar, who might simply argue that it therefore does not apply to him.
} 
to as antinatalism. ${ }^{8}$ Paying lip-service to Schopenhauer, the enigmatic pseudonymous neo-nihilist "Kurnig" also viewed these ancient Indian religions as proto-antinatalist (Akerma 2018, 5-7). Somewhat similarly, William R. LaFleur has referred to Buddhism and Confucianism as, respectively, "antifecundist" and "fecundist". ${ }^{9}$ More recently, Amy Paris Langenberg has argued that Buddhism is deeply antinatalist, rather than "merely" antifecundist. ${ }^{10}$ But, what Langenberg and LaFleur describe in their defence of Buddhist antinatalism (or antifecundism) are crowd-control measures that follow from a concern with Buddhist practitioners' (mental) wellbeing. These are not strong cases, and merely point out that Buddhism and antinatalism are not incompatible.

While Daoist monastic practice might similarly be directed at the sublimation of desire, ${ }^{11}$ the texts themselves reveal an overbearing concern with the position of the human vis-à-vis its surroundings that has more bearing on the core tenets of modern antinatalism and its radical critique of consciousness. More than crowd-control measures, these texts also seek to significantly challenge human hubris and the cosmic constant of human hegemony. We will leave behind Buddhism here and turn towards Daoism.

\section{THE CASE FOR DAOISM}

Wing-Tsit Chan begins his all-too-famous overview of Chinese philosophy with the statement that Chinese philosophy is inherently humanistic (Chan 2001, 3). ${ }^{12}$ For him this applies to Confucianism in particular. ${ }^{13}$ Although the right mix of ancestral reverence and societal responsibility is pivotal to the Confucian ethical system, good people are not solely defined by it. Rather, they are defined by their upright moral standing, and as such play an important and responsible part in society. While they are, to an important degree, still shackled by family tradition and expectations, they are given more elbow room within that position than ever before.

While this seems to be a valid statement for Confucianism at least, it cannot readily be extended to Daoism. While Daoism is certainly not indifferent to human affairs, the emphasis shifts from the purely-human to the purely-cosmic. Hans-Georg Moeller writes on this that "...Daoist philosophy, in general, is not humanist...Human beings

\footnotetext{
${ }^{8}$ Mishra argues that when considering these ancient schools of thought we get the "...inescapable conclusion that both... see worldly existence as an undesirable state, shot through with negativities of all kinds, so that escaping it altogether is the highest good possible for human beings." (Coates 2014, 41)

${ }^{9}$ What sets apart Buddhism from other systems like Confucianism, is its refusal to consider reproduction as a tool for boosting the absolute number of religious members. Childbirth is divested of its religious magnificence, and while children are not hated, they are not seen as a divine presents either. In fact, reproduction may actually prevent one from obtaining such presents at all. Thus, while not referring to Buddhism as antinatalist, LaFleur makes a convincing case that it nonetheless shares some of the tenets with what we now call antinatalism. (LaFleur 2002, 56-60)

${ }^{10}$ She writes that "... Buddhist antinatalism...is a basic component of both Buddhist soteriology and practical articulations of the path.” (Langenberg 2018, 577).

${ }^{11}$ See Kohn (2008) for more on this.

${ }^{12}$ This has been picked up in recent times by Chen Guying. See especially (Chen 2012, 134, 151).

${ }^{13}$ See for instance the following famous passages in the Lunyu 論語: 6.22, 11.12, 15.29.
} 
are one element or segment of the functioning of the cosmos. Within this scenario, there is nothing special about humans." (Moeller 2006, 55) Daoists, in other words, are not indifferent to humankind as a whole, but to some of the aspects that essentially make humans human. ${ }^{14}$ The Daoist emphasis on the cosmos, then, does not entail a neglect of human affairs. It acknowledges in sober terms the place that humankind really has in the larger cosmos.

For Daoists humans are part of the cosmic décor, but emphatically not the main actors in the play, which they are often made out to be in Confucian and other ethical writings. In Daoist texts, the focus, rather, is on the Dao 道. The well-known fortysecond chapter in the Lao-Zi contains the standard account of Daoist cosmogony. We read that,

\section{道生一，一生二，二生三，三生萬物 ${ }^{15}$}

"Way-making (dao) gives rise to continuity, continuity gives rise to difference, difference gives rise to plurality, and plurality gives rise to the manifold of everything that is happening (wanwu)." (Ames and Hall 2003, 142)

The Dao naturally comes first, followed by the cosmic components that color in the lines of its emergence, like $q i$ 氣, yin and yang 陰陽 and heaven (tian 天) and earth ( $d i$ 地). However, we must be careful not to describe these categories of existence as cosmic posterity of the Dao. ${ }^{16}$ The varieties of being that we see and feel around us are not spawned in the center of the cosmos, for the Dao pervades the entire universe and everything in it. Moreover, this all occurs without arresting the subtle movements of the Dao. Similarly, in the pre-Qin Pheasant Cap Master (Heguanzi 鶡冠子) we read,

\section{道在而不可專。切譬于淵，其深不測，淩淩乎泳澹波而不竭。}

"The Way is there but may not be monopolized. It is exactly comparable to the abyss, its depths are unfathomable. It surges on placidly, its waves are inexhaustible." (Wells 2013, 208-209)

The Dao, in other words, does not give birth to beings, it gives rise to them by infusing them with what they will become. ${ }^{17}$ Importantly, however, this process does not 'deplete' (bujie 不竭) the Dao. This process initially occurred in a cosmos devoid of humans. When humans emerged-via a process similar to the emergence and instantiation of other beings and objects - non-human forms were given names, and, as such, were kidnapped from the pool of tranquility in which they wallowed,

\footnotetext{
${ }^{14}$ See also Nelson 2009, 298.

${ }^{15}$ Most of the text from the Chinese classics in the present work has been taken from the Chinese Text Project 中國哲學書電子化計劃 accessed online.

${ }^{16}$ David Chai writes on this that "[w]herein each differs is not in its distance or proximity to the Dao; rather, it is the degree to which the Dao's creative potential has been actualized that determines this." (Chai 2016, 266)

${ }^{17}$ In the Lao-Zi 10 we read that while the Dao gives rise to all things it does not possess them (sheng er buyou生而不有).
} 
uninterruptedly infused by the Dao. This runs counter to the natural movements of the Dao. In fact, humankind assumed this position for itself by enacting a logistics of control over the natural world (or the 'non-human'). While the profound depth of the Dao is beyond human measure (buce 不測) it is, nonetheless, forcefully brought into the orbit of human understanding. In reference to the citation above, humankind 'monopolized' (zhuan 專) Dao, by treating it as a 'thing' fundamentally knowable and understandable, and on a par with other things.

This brings us to an important point: if humans emerged from the Dao like all other 'things' in the universe, how could they eventually deviate from it? There is, in other words, some potential for dissent (or at least moral rebellion) in the very nature of human existence. ${ }^{18}$ This tension runs through many texts in the Daoist corpus. I argue here that this is due to the emergence and consolidation of human consciousness as defined in the first section above.

\section{HUMAN ABERRATION}

We have seen that the Dao flows on and on without requiring human input. Although it would be an excessive humanist fallacy to claim that humankind has the power to actually impact the fluid spontaneity of the Dao, it becomes clear from the sources that there is, nonetheless, some form of frustration brought about by the very existence of the human species. In fact, as Moeller writes, "[u]nfortunately, man seems to be the greatest obstacle for the unimpeded working of the Dao." (Moeller 2006, 56) While the reasons for this are not given in the texts at our disposal, it makes sense to point our fingers at the emergence and continued operation of human consciousness as the "greatest obstacle for the unimpeded working of the Dao."

The increased appropriation of the world around us fortifies an initially inchoate capacity for consciousness. This conflicts with the unconscious acquiescence supported in many ancient Chinese scriptures available to us. If there is no Creator or ultimate Cause that can be placed at the beginning of the universe, there is, consequently, also no conscious reliance on this (or any) first principle. Rather, the focus is on unconscious tranquillity in the face of a truly meaningless and directionless universe. Brook Ziporyn affirms that "[t]here is a fundamental assumption here that conscious awareness is always purpose-driven[.." (Ziporyn 2014, 693, emphasis in original) Anything purposedriven clearly goes against the grain of the natural fluidity of the Dao. Consciousness always constitutes a mental act of appropriation, or of imposing something strictly human on something not necessarily human at all. ${ }^{19}$ This also means that

\footnotetext{
${ }^{18}$ Roger Ames referred to this potentiality as “....man's unexplained proclivity to misinterpret his reality in dichotomous terms generated out of a perception of himself as separate and distinct from the external world." (Ames 1981, 26, emphasis in original) While humans are enjoined to follow the Dao in all their endeavours, there is within them a particle of rebellion that moves them away from the Dao. It is (purposely) left unexplained why they contain this potential for disobedience.

${ }^{19}$ The unconscious (as a layer of the psyche, not a medical and mental incapacity) does not operate in the same way and can be said to naturally and spontaneously be in line with the descriptions of the Dao
} 
consciousness, as a purpose-driven movement, automatically runs counter to the fundamental unconsciousness of the Dao. This seems strange for a faculty usually championed as a key component in humanity's ascent to the very centre of the cosmos, but not so strange from the perspective of Daoist authors and thinkers.

Although the essence of consciousness is not so much excoriated, its great (and unavoidable) potential for disruption and dissent is. Consciousness is continually enlarged by the rapid increase in sensory interaction with the world around. From this, desires and preferences are formed that further strengthen this faculty of the mind. It is therefore no surprise that an important article in the classical critique of consciousness is the ultimate fallibility of the sensory apparatus. The Heguanzi, also referred to above, gives a demonstration of the easy distortion of the senses:

一葉蔽目, 不見太山, 兩豆塞耳, 不聞雷霆。道開而否, 未之聞也。

"If one leaf covers the eyes, they will not see Grand Mountain. If two beans obstruct the ears, they do not hear thunder peals. For the Way's opening to be blocked is unheard of." (Wells 2013, 104)

Although a leaf (ye 葉) is clearly much smaller than the Grand Mountain (Taishan 太 山), under certain circumstances it can hide from view things much larger than itself. When the angle is right, a leaf can eclipse a mountain. This has little to do with the leaf itself, and more with the ultimate unreliability of the eyes that perceive a (distorted) relation between it and, in this case, a mountain. Similarly, something as unmistakably loud as a thunderbolt (leiting 雷霆) can be muted by two beans (liang-dou 兩豆) used as makeshift earplugs. Again, this has little to do with some wonderful, natural capacity of beans to block out sound and rather reveals the beguiling nature of our ears. The natural magnificence of mountains and thunder can be hidden from us by the simplest trickery. Given that our senses are so easily misguided — by something as trivial as a leaf or bean - how can the information gained thereby (or, knowledge) be worth anything?

This necessarily incomplete nature of knowledge acquisition is not just bad form an epistemological point of view. It is actually far more destructive. In the Zhuang-Zi we read the lament:

甚矣夫好知之亂天下也!

"How profoundly the love of wisdom disrupts the world!"20 (Ziporyn 2009, 66)

As the senses are accorded primary status in the purchase and transaction of knowledge, the sensory apparatus is institutionalized. Those that make good use of it are extolled, and those that do not are reviled. Society thus becomes organized around the operation

we find in the canonical sources of Daoism. Consciousness is ultimately a human work, whereas the unconscious is the cosmic ingredient inside us.

${ }^{20}$ This fleshes out the more obscure statement in the Lao-Zi 18 where we read that with the appearance of wisdom (zhi-hui-chu 智慧出) emerged also great falsehood (you-da-wei 有大偽). 
of sensory knowledge-acquisition. Conscious desires and preferences are then not just formed but written in stone as a set of unholy commandments. It can easily be seen that this has consequences that far exceed the concerns of epistemology (or philosophy as such). The Zhuang- $Z i$ is one of the texts that exposes the shaky foundation on which civilization is thereby built.

By means of contrast, the Dao "itself" cannot be perceived by the senses. It is above and beyond ordinary knowledge, but not completely distinct from it, either. While access to the Dao is never actually blocked [or, at least, this is unheard of (wei-zhi-wen 未之聞)], its qualities still cannot be readily grasped. As our eyes and ears are so easily distracted by even the smallest interferences, how could we perceive the very movement of the cosmos? Again, this is not just bad for us, it actively brings about disorder here on earth (luan-tian-xia 亂天下) as we saw in the Zhuang-Zi citation above.

Conscious appropriation, then, does not offer closure, but merely reaches after the trace of something temporal and fleeting. Nonetheless, such traces are elevated to the status of actual (and useful) insight into the world at large. ${ }^{21}$ This appropriation greatly disrupts the initial tranquility and harmony of the Dao. For the more developed the conscious mind, the bigger the gap between human and non-human. But there is a natural limit to this exploitation, and humankind is beckoned to return to its root, which is the Dao. We hear this call loudest in the shortest chapter in the Lao-Zi, where we read

反者道之動。

"Turning back is how the way moves[.]" (Lau 1982, 61)

\section{THE DAOIST MOTIF OF RETURN}

The concept of 'return' ( $f a n$ 反) in the Lao-Zi is found in chapters $25,40,65$ and $78 .^{22}$ It has often been presented as part of a dialectic: there is presumed to be a constant dance of opposites that form a never-ending dynamic of change and interaction. ${ }^{23}$ This

\footnotetext{
${ }^{21}$ Chai writes on this that "[o]nly after humanity subsequently assigns them names and attributes do the myriad things leave the nourishing shelter of the Dao's mystery, placing their inborn nature in great peril in the process." (Chai 2016, 266)

${ }^{22}$ In the Lao-Zi the terms $f u$ 復 and $g u i$ 歸 are also used, but refer to much the same thing as fan (Wang 2019, 7-8).

${ }^{23}$ Qiu Taichang (2012) notes that the principle underlying this pivotal passage in the Lao-Zi has often been viewed in light of Hegelian dialectics. While this is justified to a certain point, we must appreciate where it is not. While both accounts emphasize the tendency of all things to change, their overall orientation is vastly different. In the Lao-Zi, the root of all that is, is the Dao. All things are invested with the essence of the Dao, no matter how far away they move from it. As all things are in flux, and all things revert to their original state that undergirds this flux, "all things return to the original state of Dao" 事物的运动是向本初状态一 “道” 的复归 (Qiu 2012, 13). This constitutes an ultimately restitutive movement. Hegel, on the other hand, "points out that the general trend of things is to move forward” 指 出事物发展的总趋势是向前的 (Ibid., 15).
} 
would preclude the formation of any long-lasting stability, as everything is always in flux. The center of this waltz is graced by the constantly returning, cyclical, movement of the Dao "itself". Viewed as such, "returning" corresponds to following the choreography of the Dao, which would become but one out of an almost infinite variety of movements that constantly morph into their opposites. The Dao would become nonDao, which would become the Dao, which would become non-Dao, ad infinitum. It is very likely, however, that there is another interpretation that stays closer to the text itself.

Wang Zhongjiang (2019) has recently re-evaluated the scholarship on the motif of return in the $L a o-Z i$ and has argued that only in chapter 78 does fan actually refer to 'opposite' or 'reverse' in the sense described above. Only this chapter, therefore, supports the dialectical interpretation of the text. In the other three cases, fan refers not to some cyclical interplay, but to "...the return of the myriad beings or things (including people and humanmade things) and does not indicate the return of Dao." (Wang 2019, 2, emphasis added) This is not the same as the constant transformation into opposites traditionally read into the text. On this view, fan refers to a more thoroughgoing movement of return away from something else. ${ }^{24}$

Importantly, the Dao 'itself' is excluded from this. And how could it not be? If the Dao observed the same laws (of return) that the myriad things observe (or have to observe), how could the Dao be any different from these? The Dao cannot be brought into any equation as one part among others, because the Dao cannot have an opposite, lest it would not be the Dao anymore. This would run counter to the most basic things we read in texts like the Lao-Zi (Ibid., 4). The motif of return, consequently, cannot refer to some never-ending carousel movement of the Dao "itself" (Ibid., 7). We must discuss the possibility that the return emphasized is a more total movement away from 'something' that is not to be deviated from again in the future.

We see that it is imperative for humans to return to the Dao. This is so because they have deviated from the trajectory of the Dao in the first place, otherwise it would not have been necessary for them to return at all (Ibid., 8). But since a rock or a gust of wind cannot meaningfully be said to ever deviate from the Dao-as windstorms and rockslides are natural occurrences from the perspective of the Dao, even if they are not so from the human perspective - the importance of 'returning' does not seem to apply equally to all 'things'. If this were the case, and if all of the myriad things would have to return equally, we would somehow read agency or consciousness into completely inanimate and unconscious phenomena like rocks and gusts of wind.

\footnotetext{
${ }^{24}$ Accordingly, Wang argues that 反 should rather be read as 返, also pronounced fan. This does not just apply to the Lao-Zi but is equally the case for the Zhuang-Zi (Wang 2019,7). On the motif of return in the Zhuang-Zi see also Chai 2019, 25-30. A word of caution is clearly in place here. While the motif of return may resonate similarly in certain parts of the Zhuang-Zi, there clearly are different strands of the text that would support a different interpretation, one more easily referred to as 'primitivism'. These unresolved tensions in the Zhuang-Zi are what make the text so special and should not be forcefully resolved. In other words, the primitivist strophes of the text do not contradict the passages pointing towards a more solid, holistic 'return' that precedes even earlier modes of (primitive) civilization.
} 
It appears that these natural phenomena are exempt from the dictate to return because they could not have deviated from the course of the Dao in the first place. A rock just $i s$ in the sense that a human cannot be said to just be. Vital to how we now perceive the human being is exactly by the difference between it and such passive, natural phenomena like rocks and gusts of wind. While these are perfectly natural, humans have the potential not to be 'natural', because they possess some inherent potentiality for dissent, which has been located in the faculty of consciousness. It is this aspect of the human mind that enables humans to deviate from the trajectory of the Dao. It is also this faculty that must be deconstructed if humans are to truly return to the Dao.

It could be argued that if human consciousness truly represents an aberration, an excrescence from the body of the Dao, then why did the Dao not simply block its emergence? Why, in other words, would the Dao give rise to something that annoys it, or that even goes against its cosmic grain? The reason for this is that viewing consciousness as a disturbance to the otherwise harmoniously flowing Dao is one thing. Arguing that the Dao must, as a result, take on humanlike properties in other to get rid of this disturbance, this is another. Only in later texts like the Xiang-Er 想爾 commentary to the $L a o-Z i$, does the Dao actually assume humanlike capacities in order to force humankind into obedience. In texts like these, the Dao makes it very clear that unquestioned obedience to its precepts is vital. ${ }^{25}$

This clearly speaks against earlier notions of the absolute (but also often misunderstood) passivity of the Dao, which is described as having many of the same qualities as water ( $\mathrm{Lao}-\mathrm{Zi} 8$ ). Humans can only look for clues in the movement of the Dao that may inspire them to follow suit by also assuming these qualities. People cannot be threatened or forced into flowing as spontaneously and harmoniously as the Dao. Forcing someone to do so would be like putting a gun to their head and forcing them to relax. This would be equally absurd.

In other words, if we are to flow as spontaneously as the Dao, this can only be brought about spontaneously too. Humans cannot be forced into spontaneity, not even by (some vague semblance of) the Dao. In other words, humans can only merge with the Dao, and synchronize their own qualities with those of the Dao, when this occurs spontaneously, and not forcefully. Consequently, the emergence of consciousness cannot simply be undone by force. It is up to humankind, however, to effectuate a return from the institutionalization and consolidation of consciousness at the center of all human (and even cosmic) affairs. Again, this cannot be forced by the Dao, Heaven or 'anything' else, and it is up to humans themselves. When successfully done, this would prevent the same problems from emerging in the future that necessitated this 'return' in the first place.

As we have already seen, the concept of return analysed here might be translated into a yearning for a more primitive (perhaps, pastoral or even ascetic) way of life. On this view, there have been golden ages throughout history in which humans lived simply, and in harmony with their serene, natural surroundings. The aim is, then, to

\footnotetext{
${ }^{25}$ See Zandbergen (forthcoming, 2022) for more on this.
} 
replicate exactly such a blissful society. ${ }^{26}$ But, if this is the destination of return, then nothing will prevent the development in the future of the exact same patterns that necessitated this return in the first place. In other words, if humans were simply to return to an earlier phase of human history (no matter how far back this might be), they could not guarantee that somewhere down the line they would not end up with the same problems all over again, which would require yet another return to an earlier stage and so on. It is more likely that a more permanent return is envisioned, one that will preclude any further move away from the Dao.

The emphasis is not so much on the corrupted world of today, but rather on the primal purity of the Dao which necessarily precedes it. What we see is that our texts do not aim for a social movement away from the present state of existence and into the greener pastures of some romanticized past. Rather, this movement of return is cosmically sanctioned and responds to the emergence of even rudimentary aspects of human civilization as a token of higher modes of institutionalized consciousness. The point is not that civilisation has taken a wrong turn. The point is that civilisation came into existence at all. Consequently, there is no utopian striving for a perfect human world in which everything is equal and fair, and humankind lives peacefully ever after. In fact, there is no nostalgia for anything in human history at all. The focus is on the emergence of human history itself and the movement of return is to pass by this point in space and time. Ultimately this goes far beyond the pursuits of human betterment and the streamlining of society. ${ }^{27}$

As hinted at above, the mascots of this movement of return are sages (shengren 聖 人), and their project has a clear cosmic dimension. Because of this, Michael Puett squeezes the concept of return in the Lao-Zi into the long line of self-divinization literature that forms one of the main waterways in the Chinese intellectual landscape. He writes that

[t] he crucial point here is that the sage does not strive simply to understand, follow an accord with the generative process of the Way. On the contrary, the sage reverses that generative process and returns to the source of power[.] (Puett 2002, 166)

\footnotetext{
${ }^{26}$ Xiang Shiling (2007) affirms that the motif of return - in the guise of fan-ben 反本 (returning to the root) and fu-xing 复性 (recovering nature) - is of unremitting importance in the whole of Chinese philosophy. Moreover, it is what sets apart Chinese philosophy from its Western counterpart focused on transcendence (Xiang 2007, 24). Fanben and fuxing are part of the artery that reaches to the heart of existence, which is, at the same time, the kernel of nature. Unfortunately, Xiang fails to appreciate the metaphysical implications of 'returning' and locates it in exactly such counter-civilizational dissatisfaction of the times. Accordingly, we read of "a return to some wondrous golden age of virtue" 回复到上古的道德之世 (Ibid., 25).

${ }^{27}$ The Lao-Zi 80 seems to contradict this in quite strong terms. However, the idyllic 'society' portrayed there clearly cannot be synchronized with the Dao which is beyond any form of human comprehension. If this were not the case then this 'society' would have to be so far removed from what we understand to be 'human' that it does not make sense anymore to refer to this in strictly human terms. It would, then, be some sort of metaphor for a transhumanist fantasy, which might resemble humanity only in form.
} 
The Lao-Zi recommends not just some spiritual exercise (or series of exercises) by means of which the adept beholds the Dao or any cosmic foundation. Rather, sages actually return to the Dao as the ancestor of all that is, by mirroring its very qualities such as tranquillity and equanimity. As mentioned before, these qualities cannot be grasped by the tentacles of human consciousness. Therefore, sages forego conscious knowledge acquisition and the institutionalization thereof and return to the Dao unadorned and unbothered by the concerns, desires and preferences of ordinary humans. This makes a different caste of beings altogether.

\section{SAGEHOOD}

Although ordinary humans generally do not take center stage, sages do enjoy a special place in the cosmic scheme of the $\mathrm{Dao}^{28}{ }^{28}$ For these sages participate in the rectification of the hindrance of humankind by leaving the ranks of their fellow beings and returning to the Dao. As such, they are not concerned about the quotidian affairs of differentiating between polar opposites, such as right and wrong, beautiful and ugly, true and false, etc. It is exactly such judgment that "...constitutes the particular "human" aspect that is overcome by the sage - and by the sage alone[.]" (Moeller 2006, 134) This is not to say that sages are hermits that exit society in order to face the terrors of existence in full, naked contemplation in order to reach some higher understanding of the world around them. That choice, in fact, could easily be criticized from a Daoist perspective too, for one would still essentially be entrenched in human society, just at a greater distance from the epicenter. In fact, such distance-and physical parameters in general - are not what make sages sagely.

What is called for, rather, is a more profound effort: the very flow of conscious knowledge-acquisition must be arrested and reversed. Only then can sages return to the root of their existence, which is the Dao. In the Lao-Zi 16 we read that this return (gui 歸) ${ }^{29}$ to the root (gen 根) is called stillness (yue-jing 日靜). This stillness (which joins other metaphors like tranquility and harmony) is the very atmosphere of the Dao, and can only be achieved by relinquishing desires, preferences and the overall state of consciousness associated with ordinary human existence. At the most basic level, what this calls for is the radical moderation of sense perception that gives rise to such desires and preferences and which continually consolidates conscious control over the nonhuman. Only then can one can be said to be able to return to, and merge with, the root 根 of the Dao. A helpful illustration of this occurs in the "Basic Warp" (Ben-Jing 本 經) chapter in the Huai-Nan-Zi 淮南子 where we read that when one obstructs the four portals (bi siguan 閉四關) of perception (the eyes, ears, mouth and heart-mind) one is submerged in the Dao (yu-dao-lun 與道淪). At this point,

\footnotetext{
${ }^{28}$ In $\mathrm{Lao}-\mathrm{Zi} 25$ we read that the sage is one of the four greats (si- $\mathrm{da}$ 四大) alongside Heaven, Earth and Dao.

${ }^{29}$ As mentioned above, the argument was made by Wang (2019) that gui functions much the same as fan.
} 
目明而不以視, 耳聰而不以聽

“...the eyes are clear, but they are not used for seeing; and the ears are comprehensive, but they are not used for hearing[.]" (Major et al. 2010, 280)

In other words, sages are able to merge with the Dao when they give up their reliance on the sensory apparatus. They are then unobstructed by the imperfect design of the portals of perception and unconstrained by the formation of knowledge based upon this. It is important to note that the key here is not just sensory deprivation. Otherwise anyone floating around in an isolation tank would be a sage. Rather, what counts is the foregoing of knowledge-acquisition via the sensory apparatus and the complete openness to a more direct, yet incommunicable, intuition of the Dao. Only in this way do sages (to-be) disinvest themselves from institutionalized consciousness at the very center of the human project. This ultimately releases them from the concerns of ordinary human beings, too. This might certainly make them appear strange from the perspective of ordinary human existence.

In the “The Great Source as Teacher" (Da-Zong-Shi 大宗師) chapter in the Zhuang$Z i$, Confucius sends his disciple Zigong 子貢 to attend the mourning process of a certain Zisanghu 子桑戶. Upon his arrival, however, Zigong finds the dead man's companions Mengzifan 孟子反 and Ziqinzhang 子琴張 playing music and singing. Having expected a proper mourning ritual, Zigong asks the two men about their unseemly behavior. They then look at each other and laugh (er-ren-xiang-shi-er-xiao 二人相視而笑) and proceed to question his - Zigong's own - knowledge of proper ritual (zhi-li-yi 知禮意). Amazed at this, Zigong returns to his master and asks about these two men. Confucius replies that

\section{彼以生為附贅縣疮, 以死為決疯潰㾗。}

"Men such as these look upon life as a dangling wart or swollen pimple, and on death as its dropping off, its bursting and draining." ${ }^{\prime 30}$ (Ziporyn 2009, 47)

A careful equanimity is displayed here. These men are sages and look at life as something that has simply occurred. While an excrescence like a tumor (you 病) may issue from the human body itself, this does not make it an intrinsic or necessary quality of that human body. The potentiality for growth (in whichever direction) is no justification for such growth in the first place. For the process of change, in this sense, may be completely unnecessary and even lethal. The fact that tumors are, nonetheless, born inside (or on) the body is irrelevant here.

And so it is with human life in general: its occurrence does not make it absolutely necessary or good for its own sake. There may not have been a reason for its occurrence. Life may well have been very different, or not at all. The fact that life has happened does not justify it. Recognizing that others attach too much importance to life simply because it is so, sages maintain a healthy distance from it. While sages can view the process of growth in these terms, non-sages cannot. The overwhelming majority of

${ }^{30}$ In the Lao-Zi 20 some of the key differences between the sage and non-sage are similarly listed. 
humankind is unduly attached to even the most transient aspects of life, exposed here by these "strangers".

It is imperative, however, that this situation does not persist. Although sages are very different from ordinary humans, they $d o$ have a responsibility towards the world around them. In the Lao-Zi 3 we read that sages must keep the populace free from knowledge and desires ( $w u-z h i w u-y u$ 無知無欲). Those that already have knowledge, however, must be instructed not to act upon it (bu-gan-wei 不敢為). Only in this way can people be prompted to follow in the footsteps of sages and forego the easy gratification offered by human consciousness and the formation of desires and preferences. $^{31}$

But this is not to say that the potential universalization of sagehood would completely make up for the damage done by human consciousness. Its avoidance would have been far better than its eventual repair. In the "Quintessential Spirit" (Jing-shen 精神) chapter in the Huainanzi we read the following important, yet often overlooked passage:

冰之凝, 不若其釋也, 又況不為冰乎!

"Ice is better once it melts; how much better if it had never been frozen." (Major et al. 2010, 257)

The ascription of water-like properties to the Dao flows through the whole history of Daoist philosophy. Water represents the unconscious flow of the Dao through the universe. Sages are to take on this flowing quality too. Free-flowing water can be opposed to ice, which is an excellent metaphor for the inertia of ordinary conscious existence. The natural fluidity of unconscious Dao is arrested in the ice that represents human disruption and turgidity via consciousness.

In the Lao-Zi 15 a description is given of those of old who possessed Dao. They cannot be described directly, however, as their qualities mirror those of the Dao and these cannot be comprehended by ordinary means or conveyed by ordinary language either. These qualities can only be gestured at (or imperfectly captured in metaphors). One of the ways in which this is done is by the impression that these men are as fleeting as ice that is about to melt (huan-xi-ruo-bing-zhi-jiang-shi 渙兮若冰之將釋). ${ }^{32}$ In other words, sages return to the natural fluidity of water, and away from the stubborn immobility of ice. This constitutes a passage from human consciousness to the unconscious Dao. In the “Mountain of Persuasions” (Shuo-Shan-Xun 說山訓) chapter in the Huainanzi we also read that melting ice enables the return to the Ancestor (yi-qifan-zong 以其反宗), which is but another alias of the Dao. Liberating oneself from the

\footnotetext{
${ }^{31}$ In Lao-Zi 28 we read that sages, like the Dao after which they are modeled, cannot resort to violence (bu-ge 不割) to achieve this. As mentioned before, this 'goal' can only be achieved spontaneously.

${ }^{32}$ In the Xiang-Er commentary we read that this applies to one's emotions, desires, thoughts and considerations (qing-yu-si-lu 情欲思慮) all unwanted by the Dao (dao-by-suo-yu 道不所欲). Because of this, one's heart-mind ( xin 心) is instructed to make these scatter like ice in the sun (ling-ru-bing-jianri-san-zhuo 令如冰見日散汋). See also Bokenkamp 1999, 98.
} 
coarse immobility of ordinary, conscious human existence, therefore, enables one to return to the Dao as the Ancestor of all that is.

Although ice occurs naturally, the spontaneous movement of water is arrested when it takes on this form. And although we can retrieve some of the properties of freeflowing water when we melt the ice again, some of these spontaneous qualities will inevitably evaporate and be lost. Therefore, it would have been better if the natural propensity of water to flow had not been interrupted in the first place. Likewise, while the institution of sagehood can rectify the problems brought about by the enshrinement of consciousness in human civilisation, it would have been better if this rectification had not been necessary and consciousness had never come into existence in the first place. Likewise, in the case of sickness, prevention is the best cure. While it is clearly good to be cured of a disease, it would have been far better if this disease had never struck us. Thus, while it would have been preferable from the perspective of the Dao if consciousness had never emerged, it eventually did emerge and cannot simply be removed by force anymore. This can only be done spontaneously and naturally when human beings relinquish consciousness and thereby return to the Dao whence they came.

\section{CONCLUSION}

In this article I shed light on an important coincidence of ideas about the emergence and continued operation of human consciousness. I argued that classical Daoism and modern antinatalism engage in an interesting dialogue about the damage done by consciousness, and the ultimate solution to this problem. This solution, radical as this may sound, is found in the dissolution of consciousness. While this is mapped out in different ways in the respective texts discussed above, it is also recognized that this is no easy matter and results may be difficult to obtain. Both accounts, however, emphasize a movement of return away from the strictures of consciousness.

For antinatalism, the dismantling of the artifice of consciousness is achieved by the slow but steady extinction of the human species via the mass-abstention from reproduction. Although antinatalism is not spelled out in the Daoist texts discussed here, the overall argument seems to rely on that which hides behind this contentious term as well. We have seen that the movement of return emphasized in texts like the Lao-Zi coincides with the institutionalization of sagehood. Only by entering the trajectory of sagehood can human beings undo the damage done by their cherished consciousness. While sages may resemble human beings, they are far detached from the ideal of ordinary conscious human existence that we know. Moreover, while they may still physically inhabit the world of humans, in reality they have returned to the Dao.

\section{ACKNOWLEDGEMENTS}


This essay builds on topics first explored in my doctoral dissertation "Between Iron Skies and Copper Earth: A Post-Comparative Philosophical Attempt at Measuring the Diaphysis of the Human Predicament as the Conscious Condition." I would like to express my gratitude to the anonymous peer-reviewers of the journal Comparative Philosophy who provided me with helpful and erudite comments.

\section{REFERENCES}

Akerma, K. (2018), "Kurnig-The First Modern Antinatalist", self-published. $<$ https://antinatalismblog.wordpress.com/2018/07/07/kurnig-the-first-modernantinatalist $/>$

Ames, R. T. (1981), “Taoism and the Androgynous Ideal”, Historical Reflections / Réflexions Historiques 8:3: 21-45.

Ames, R. T. and Hall, D. L. (trans., ed.) (2003), Dao De Jing: A Philosophical Translation (New York City: Ballantine Books).

Belshaw, C. (2012), "A new argument for anti-natalism", South African Journal of Philosophy 31: 117-127. <https://doi.org/10.1080/02580136.2012.10751772>

Benatar, D. (2006), Better Never to Have Been: The Harm of Coming into Existence (Oxford: Oxford University Press). <https://doi.org/10.1080/02580136.2012. 10751773>

Benatar, D. (ed.) (2010), Life, Death, and Meaning: Key Philosophical Readings on the Big Questions (Lanham, Maryland: Rowman \& Littlefield Publishers).

Benatar, D. (2012), "Every Conceivable Harm: A Further Defence of Anti-Natalism", South African Journal of Philosophy 31: 128-164. <https://doi.org/10.1080/ 02580136.2012.10751773>

Benatar, D. and Wasserman, D. (2015), Debating Procreation: Is it Wrong to Reproduce? (Oxford and New York: Oxford University Press). <https://doi.org/ 10.1093/acprof:oso/9780199333547.001.0001>

Bokenkamp, S. (1999 [1997]), Early Daoist Scriptures (Berkeley, Los Angeles and London: University of California Press). <https://doi.org/10.1093/acprof:oso/ 9780199333547.001.0001>

Chai, D. (2016), "Rethinking the Daoist Concept of Nature", Journal of Chinese Philosophy 43.3/4: 259-274.

Chai, D. (2019), Zhuangzi and the Becoming of Nothingness (Albany, NY: State University of New York Press). <https://doi.org/10.1111/1540-6253.12262>

Chan, W. T. (2001 [1963]), A Source Book in Chinese Philosophy (Princeton, N.J: Princeton University Press). $<$ https://doi.org/10.1515/9781400820030>

Chen Guying 陈鼓应 (2012), 《道家的人文精神》 [Daoist Spirit of Humanism] (北 京 Beijing: 中华书局).

Coates, K. (2016), Anti-Natalism: Rejectionist Philosophy from Buddhism to Benatar (Sarasota, Florida: First Edition Design Publishing). 
Kohn, L. (2008), "Sexual Control and Daoist Cultivation", in C. Olson (ed.), Celibacy and Religious Traditions (Oxford: Oxford University Press), 241-263. <https:// doi.org/10.1093/acprof:oso/9780195306316.003.0013>

Lafleur, W. R. (2002), "Sex, Rhetoric, and Ontology Fecundism as an Ethical Problem", in S. Ellingson and M. C. Green (eds.), Religion and Sexuality in Cross-Cultural Perspective (London and New York: Routledge), 51-82.

Langenberg, A. P. (2018), "Buddhism and Sexuality", in D. Cozort and J. M. Shields (eds.) The Oxford Handbook of Buddhist Ethics (Oxford: Oxford University Press), 567-591. < https://doi.org/10.1093/obo/9780195393521-0244>

Lau, D. C. (trans.) (1982), Tao Te Ching (Hong Kong: The Chinese University Press).

Major, J. S. et. al. (2010), The Huainanzi: A Guide to the Theory and Practice of Government in Early Han China (New York: Columbia University Press).

Moeller, H. G. (2006), The Philosophy of the Daodejing (New York: Columbia University Press).

Nelson, E. S. (2009), "Responding with Dao: Early Daoist Ethics and the Environment", Philosophy East and West 59.3: 294-316. <https://doi.org/10.1353/ pew.0.0061>

Puett, M. J. (2002), To Become a God: Cosmology, Sacrifice, and Self-Divinization in Early China (Cambridge, Massachusetts: Harvard University Asia Center). $<$ https: //doi.org/10.1163/9781684170418>

Qiu Taichang 邱太昌 (2012), ““反者道之动”与 “否定之否定规律” 比较研究” [A Comparative Study of (the Concepts of) "Turning Back is How the Way Moves" and “The Law of Double Negation"], 《社会科学前沿》[Frontiers of Social Sciences] 1 (2012): 11-16.

Schönegger, P. (2021, forthcoming), "What's up with Anti-natalists? An Observational Study on the Relationship between Dark Triad Personality Traits and Anti-natalist Views", Philosophical Psychology: 1-29. <https://doi.org/10.1080/09515089. 2021.1946026>

Smuts, A. (2014), "To Be or Never to Have Been: Anti-Natalism and a Life Worth Living", Ethical Theory and Moral Practice 17:4, Special Issue: BSET-conference 2013: 711-729. <https://doi.org/10.1007/s10677-013-9461-0>

Wang Zhongjiang 王中江 (2019), "Abnormalities and Return: An Exploration of the Concept Fan 反 in the Lao-Zi", Religions 10.32: 1-20<https://doi.org/10.3390/ rel10010032>

Wells, M. (2013), The Pheasant Cap Master and the End of History (St. Petersburg, FL: Three Pines Press).

Xiang Shiling 向世陵 (2007), “中国哲学 “反本” “复性”论研究” [A Study on the Theory in Chinese Philosophy of Returning to the Root and Recovering Original Nature], 《中国人民大学学报》 [Journal of Renmin University] 5 (2007): 24-31.

Zandbergen, R. (2021a), "Between Iron Skies and Copper Earth: Antinatalism and the Death of God", Zygon: Journal of Religion and Science 56:2: 374-394. $<$ https://doi.org/10.1111/zygo.12668> 
Zandbergen, R. (2021b), "Wailing from the Heights of Velleity: A Strong Case for Antinatalism in these Trying Times", The South African Journal of Philosophy 40:3: 265-278. <https://doi.org/10.1080/02580136.2021.1949559>

Zandbergen, R. (forthcoming, 2022), "The Ludibrium of Living well: a Re-evaluation of the Religious Worldview of the Xiang'er Commentary to the Lao-Zi 老子想爾 注”, Monumenta Serica - Journal of Oriental Studies.

Ziporyn, B. (trans., ed.) (2009), Zhuangzi: The Essential Writings: With Selections from Traditional Commentaries (Indianapolis : Hackett Publishing Company, Inc.).

Ziporyn, B. (2014), "The Importance of Being God-Less: The Unintended Universe and China's Spiritual Legacy", Journal of Chinese Philosophy 41.S1: 686-708. $<$ https://doi.org/10.1163/15406253-04105011> 